\title{
Poly IC
}

National Cancer Institute

\section{Source}

National Cancer Institute. Poly IC. NCI Thesaurus. Code C758.

A synthetic polyinosinic-polycytidylic acid double-stranded RNA. Poly IC may stimulate the release of cytotoxic cytokines and, by inducing interferon-gamma production, may increase the number and tumoricidal activities of various immunohematopoietic cells.

$(\mathrm{NCl04})$ 